\title{
Influence of Altitude and Environmental Temperature on Muscle Functional and Mechanical Activation After 30' Time Trial Run
}

Rojas-Valverde, Daniel; Ugalde-Ramírez, Jose Alexis; Sánchez-Ureña, Braulio; Gutiérrez-Vargas, Randall Influence of Altitude and Environmental Temperature on Muscle Functional and Mechanical Activation After 30'

Time Trial Run

MHSalud, vol. 17, núm. 1, 2020

Universidad Nacional, Costa Rica

Disponible en: http://www.redalyc.org/articulo.oa?id=237061117002

DOl: https://doi.org/10.15359/mhs.17-1.2

Esta obra está bajo una Licencia Creative Commons Atribución-NoComercial-SinDerivar 3.0 Internacional. 
MHSALUD, ISSN: 1659-097X, 17(1), ENERO-JUNIO, 2020, PP 1-14

Rojas-Valverde, Ugalde-Ramírez, Sánchez-Ureña, Gutiérrez-Vargas

\title{
Influence of Altitude and Environmental Temperature on Muscle Functional and Mechanical Activation After 30' Time Trial Run
}
Influencia de la altitud y la temperatura ambiental en la activación muscular mecánica y funcional posterior a una carrera contrarreloj de 30'

Influência da altitude e da temperatura ambiental na ativação muscular mecânica e funcional depois de uma corrida de velocidade de $30^{\prime}$

Daniel Rojas-Valverde

Universidad Nacional, Escuela Ciencias del Movimiento

Humano y Calidad de Vida, Costa Rica

drojasv@hotmail.com

iD http://orcid.org/0000-0002-0717-8827

Jose Alexis Ugalde-Ramirez

Universidad Nacional, Escuela Ciencias del Movimiento

Humano y Calidad de Vida, Costa Rica

a.ugalde07@hotmail.com

(iD) http://orcid.org/0000-0003-3247-9960

Braulio Sánchez-Ureña

Universidad Nacional, Escuela Ciencias del Movimiento

Humano y Calidad de Vida, Costa Rica

brau09@hotmail.com

iD http://orcid.org/0000-0001-8791-6836

Randall Gutiérrez-Vargas

Universidad Nacional, Escuela Ciencias del Movimiento

Humano y Calidad de Vida, Costa Rica

randall.gutierrez.vargas@una.cr

iD http://orcid.org/0000-0003-4187-3484
DOI: https://doi.org/10.15359/mhs.17-1.2

Redalyc: http://www.redalyc.org/articulo.oa? id $=237061117002$

Recepción: 18 Marzo 2019

Aprobación: 02 Octubre 2019

\begin{abstract}
:
The purpose of this study was to explore the influence of altitude and environmental temperature on muscle mechanical and functional activation after 30' Time Trial run (30' TT). Twenty physical active males (Age $=20.4 \pm 3.21$ years, VO2 max $=47.2$ $\pm 5.2 \mathrm{ml} / \mathrm{kg} / \mathrm{min}$ ) performed a 30' TT in three different conditions of altitude and temperature: Control Condition [CC] (1137 m.a.s.l. at $26 \pm 1.5^{\circ} \mathrm{C}$ ), Heat-Low Condition [HLC] (3 m.a.s.l. at $30.5 \pm 0.6^{\circ} \mathrm{C}$ ), and Cool-High Condition [CHC] (2369 m.a.s.l. at $\left.14.2 \pm 0.6^{\circ} \mathrm{C}\right)$. Tensiomyography (TMG), Countermovement Jump (CMJ), and Delayed Onset Muscle Soreness (DOMS) were measured pre and post running. During the 30' TT, distance, speed, heart rate (HR), rate of perceived exertion (RPE), and thermal index (WBGT) were measured. Results show a significant decrease in body weight and a significant increase in DOMS and jump height in CMJ after running in each condition. TMG responses increased maximum radial muscle displacement (Dm) and decreased muscle contraction time ( $\mathrm{Tc}$ ) both rectus and biceps femoris muscles after running. During the 30' TT, the results did not show a significant difference in RPE, HR, distance, and speed among conditions. In conclusion, altitude and temperature seem not to significantly affect the mechanical and functional responses 30' TT, despite the tendency of HLC to decrease both activation and performance.
\end{abstract}

KEYWORDS: muscles, running, altitude, temperature, tensiomyography.

\section{Resumen:}


El objetivo de este estudio fue determinar si la altitud y la temperatura ambiental influyen en la activación funcional y mecánica, en el nivel muscular, después de 30' de carrera contrarreloj. Veinte hombres físicamente activos (edad $=20,4 \pm 3,21$ años, VO2máx $=47,2 \pm 5,2 \mathrm{ml} / \mathrm{kg} / \mathrm{min}$ ) realizaron 30' de carrera contrarreloj (30'TT) en tres diferentes condiciones de altitud y temperatura: condición control [CC] $\left(1137 \mathrm{msnm}, 26 \pm 1.5^{\circ} \mathrm{C}\right)$, condición caja y calor [HLC] $\left(3 \mathrm{msnm}, 30.5 \pm 0.6^{\circ} \mathrm{C}\right)$ y condición de altura y frío [CHC] $\left(2369 \mathrm{msnm}, 14.2 \pm 0.6^{\circ} \mathrm{C}\right)$. Tensiomiografía (TMG), salto contramovimiento (CMJ) y dolor muscular de aparición tardía (DOMS) se midieron antes y después de la carrera. Durante los 30'TT, se calcularon la distancia, la velocidad, la frecuencia cardíaca (FC), el esfuerzo percibido (RPE) y el índice de estrés térmico (WBGT). Los principales resultados muestran una disminución significativa en el peso corporal y un aumento significativo tanto en el DOMS como en la altura de salto en CMJ, después de correr en cada condición. Las respuestas de TMG aumentaron el desplazamiento muscular radial máximo (Dm) y el tiempo de contracción muscular $(\mathrm{Tc})$, en el recto femoral y en el bíceps femoral, luego de correr. Durante el 30'TT, los resultados no mostraron una diferencia significativa en el RPE, la FC, distancia y velocidad entre las condiciones. En conclusión, la altitud y la temperatura parecen no afectar significativamente las respuestas mecánicas y funcionales después de 30' de carrera contrarreloj, a pesar de la tendencia de la condición HLC de disminuir la activación y el desempeño de la prueba.

Palabras Clave: músculos, carrera, altitud, temperatura, tensiomiografía.

\section{Resumo:}

O objetivo deste estudo foi determinar se a temperatura ambiente e a altitude influenciam a ativação funcional e mecânica a nível muscular após 30' de corrida de velocidade. Vinte homens fisicamente ativos (idade $=20,4 \pm 3,21$ anos, VO2máx $=47,2 \pm 5,2$ $\mathrm{ml} / \mathrm{kg} / \mathrm{min}$ ) realizaram 30' de corrida de velocidade (30'TT) em três condições diferentes de altitude e temperatura: Condição de controle [CC] $\left(1137 \mathrm{msnm}, 26 \pm 1,5^{\circ} \mathrm{C}\right.$, Condição do corpo e calor [HLC] $\left(3 \mathrm{msnm}, 30,5 \pm 0,6^{\circ} \mathrm{C}\right)$ e condição de altura e frio [CHC] (2369 msnm, 14,2 \pm 0,6). Os valores de Tensiomiografia (TMG), salto de contra movimento (CMJ) e dor muscular de início tardio (DOMS) foram medidos antes e depois da corrida. Durante 30' TT, a distância, a velocidade e a frequência foram medidas, como também a frequência cardíaca (FC), o esforço percebido (RPE) e o índice de cansaço térmico (WBGT). Os principais resultados mostram uma diminuição significativa no peso corporal e um aumento significativo no DOMS e na altura do salto na CMJ, após a corrida em cada condição. As respostas da TMG aumentaram o deslocamento muscular radial máximo $(\mathrm{Dm})$ e o tempo do músculo contraído $(\mathrm{Tc})$ no reto femoral e bíceps femoral, após a corrida. Durante o 30'TT, os resultados não mostraram diferença significativa na RPE, na FC, na distância e na velocidade entre as condições. Em conclusão, altitude e temperatura parecem não afetar significativamente as respostas mecânicas e funcionais após 30 minutos de corrida de velocidade, apesar da tendência da condição HLC de diminuir a ativação e o desempenho do teste.

PalaVras-CHAVE: músculos, corrida, altitude, temperatura, tensiomiografia.

\section{INTRODUCTION}

The evolution of physical training is constant. Over the years, different ways of increasing physical performance have been studied by testing the effectiveness of different activation methods prior to training and competition. One of these methods is the activation after specific exercising or also known as Post Activation Potentiation (PAP). It is understood as a temporary increase in functional physical capabilities influencing performance (Lorenz, 2011; Tano, Bishop, Berning, Adams \& DeBeliso, 2016). PAP phenomenon occurs after conditioning activity with submaximal and maximum exercises, provoking an increase in the capacity of the striated skeletal muscle to produce strength (Lorenz, 2011). Muscle contractions generated in the activation exercises cause a greater force in subsequent motor actions (Esformes, Cameron, \& Bampouras, 2010).

According to different studies, the mechanisms of PAP are based in the improvement of the phosphorylation of the myosin chains that cause the protein filaments of actin and myosin to become more sensitive to the release of calcium, which also stimulates a greater recruitment of motor units (Chatzopoulos et al., 2007; DeRenne, 2010; Wilson et al., 2013). PAP improves muscle stiffness and tone, increasing the strength and power capacities (DeRenne, 2010; Wilson et al., 2013), and contributing to the improvement of muscular endurance (Mettler \& Griffin, 2012). However, PAP effects may be modulated by different factors, such as intensity load, volume of training, rest intervals and the type of exercise performed (Gouvêa, Fernandes, César, Silva, \& Gomes, 2012; Seitz \& Haff, 2016; Wilson et al., 2013; Xenofondos et al., 2010). 
PAP interventions are based on complex training, combining external load with specific sports activities (Gołaś, Maszczyk, Zajac, Mikołajec, \& Stastny, 2016).

The most common methods implemented to produce PAP stimulus are maximal repetition (1RM), squat, haft squat, and jumping (Wilson et al., 2013). It has demonstrated an enhancement in sprint ability after ten single repetitions at $90 \%$ of $1 \mathrm{RM}$ (Chatzopoulos et al., 2007) and after one set of three repetitions of the back squat at $91 \% 1 \mathrm{RM}$ in professional rugby players (Bevan et al., 2010). In football players after PAP as a warmup strategy, an improvement in a sprint and horizontal plane muscular power output was observed (Tano et al., 2016). On the other hand, other authors have reported improvements in countermovement jump tests after two different field running protocols in endurance runners (Boullosa \& Tuimil, 2009). Likewise, after fatiguing running exercises, improvements in neuromuscular responses in elite resistance runners have been indicated (Vuorimaa, Virlander, Kurkilahti, Vasankari, \& Häkkinen, 2006). Also, in a recent systematic review of the effect of PAP on jump performance, there is evidence regarding the effect of squat repetitions on the vertical jump performance as well as weightlifting Olympic actions as clean and jerks (Picón-Martínez, Chulvi-Medrano, Cortell-Tormo \& Cardozo, 2019).

Other studies have investigated the effect of training on performance in different environmental conditions such as altitude (Hamlin, Hopkins, \& Hollings 2015; Lundby, Millet, Calbet, Bärtsch, \& Subudhi, 2012). The combination of hypoxia conditions with physical training during a certain period is an effective stimulus to produce changes in skeletal muscle tissue, increasing oxidative muscle capacity (Geiser et al., 2001). However, in high altitudes, muscles have lower fiber recruitment by the nervous system, decreasing the speed and strength of the muscular contractions, causing explosive actions (Feriche et al., 2014).

The effects of training at different altitudes on neuromuscular responses have also been studied. However, the effects in muscle contractile properties under hypoxia conditions seem to be unclear. In a study conducted on athletes, when comparing low vs high altitude, changes were observed in the maximum radial displacement $(\mathrm{Dm})$ and reaction time $(\mathrm{Td})$ of the biceps femoris and vastus lateralis $(\mathrm{VL})$ muscles due to hypoxia, where muscle radial displacement suffered reductions, understood as an increase in muscle stiffness (Morales-Artacho et al., 2015). Conversely, under hypoxia conditions, there was no indication of a significant impact on contractile properties of skeletal muscle of the leg which, assessed electrically, evoked isometric contractions (Degens, Homeros, \& Hopman, 2006). In fact, it had indicated similar peripheral and neuromuscular responses in normoxic and hypoxic conditions during sustained fatiguing contractions after 90" of maximal voluntary contraction (Szubski, Burtscher, \& Löscher, 2007).

Based on the information above, different studies have assessed the effect of the different PAP methods such as plyometrics, sprint, squat, and jumping on the neuromuscular performance. Nevertheless, few investigations (Boullosa \& Tuimil, 2009; Vuorimaa et al., 2006) have analyzed the effects of running protocols on PAP. In addition, there is no evidence of the influence some environmental conditions, such as altitude and temperature, have on PAP in runners. Therefore, the objective of this study was to explore the influence of altitude and environmental temperature on muscle mechanical and functional activation after 30' TT.

\section{Methodology}

\section{Participants}

Twenty well trained and physically active male adults (Age $=20.4 \pm 3.21$ years, $\mathrm{VO} 2 \mathrm{max}=47.2 \pm 5.2 \mathrm{ml} / \mathrm{kg}$ / min, weight $=67.82 \pm 8.93 \mathrm{~kg}$ ) were part of this study. Participants who exercised $>30 \mathrm{~min}$, two to three times a week, were selected according to the Physical Activity Scale (Pastor, Balaguer, \& García-Merita, 1999). Those participants who reported injury or neuromuscular conditions that did not allow them to perform 
endurance intensive efforts were excluded from the study. After being informed about the protocol and all possible risks associated with participation in the study, the subjects provided written consent to participate in all procedures. The research protocol followed the principles of the Declaration of Helsinki regarding biomedical research involving human subjects (World Medical Association, 2013).

\section{Instruments}

Body composition: an HD-313 Tanita (Tanita Corporation', Tokyo, Japan) with a precision of $\pm 0.1 \mathrm{~kg}$ was used to assess the total body mass $(\mathrm{kg})$. Height was measured using a wall stadiometer. To estimate the VO2max, each participant performed the Cooper Test, and the VO2max was calculated using the formula (Martínez-López, 2004): 22.351* distance (km) - 11.288.

Perceptual Scales: the Delayed Onset Muscle Soreness (DOMS) was assessed using a $10 \mathrm{~cm}$ visual analog scale of pain with a tag on each end, $0=$ no pain, and $10=$ extreme pain (Gulick, Kimura, Sitler, Paolone, $\&$ Kelly, 1996). The participants were asked to make a squat and report the perceived pain. The Rate of Perception Exertion (RPE) Scale was used to assess the perceived effort made during the 30' TT using a modified Borg scale from $0=$ no exertion to $10=$ maximum exertion.

Kinematic variables: to measure kinematic variables [i.e., average speed $(\mathrm{km} / \mathrm{h})$, distance $(\mathrm{m})$ and impacts (g-forces)] during the run, 20 inertial measurement units (IMU) at $15 \mathrm{~Hz}$ (GPS) (SP PRO X II GPSports ${ }^{\circ}$ ) were used. Test and re-test reliability of IMU devices is $r=0.75$ (Johnston, Watsford, Kelly, Pine \& Spurrs, 2014). Manufacturer software V2.5.4 firmware AMS ${ }^{\oplus}$ Team (GPSports, Canberra, Australia) was used for data analysis. Twenty heart rate (HR; beats per minute, bpm) monitors were used to analyze HR response. IMU and HR were attached to the participants $15 \mathrm{~min}$ before time-trial started using a special harness and monitor band respectively (Pino-Ortega et al., 2019).

Environmental temperature: for the assessment of the WBGT thermal stress index, a heat stress monitor (QuestTemp 36, 3MTM) was used. The equipment was calibrated according to the manufacturer and placed on a tripod $50 \mathrm{~m}$ from the start of the $30^{\prime}$ TT track.

Functional Muscle Performance: to access the functional performance, two countermovement jumps $(\mathrm{CMJ})$ was measured using the validated MyJump2 ${ }^{\circ}$ App, iPhone $6 \mathrm{~s}$ (camera with $4 \mathrm{~K}$ video at 30fps) developed and validated (ICC $=0.997, \mathrm{p}<0.001$, force platform comparison of $\mathrm{r}=0.995, \mathrm{p}<0.001$ ) (Balsalobre-Fernández, Glaister \& Lockey, 2015). The subjects were asked to stand on the floor with their legs separated at shoulders width and their hands on their waist (Sánchez-Ureña, Rojas-Valverde \& Gutiérrez-Vargas, 2018). After a signal, they made an explosive jump recorded by a researcher at $1.5 \mathrm{~m}$ following the protocol used (Balsalobre-Fernández, Glaister, \& Lockey, 2015).

Neuromuscular assessment: a tensiomyography (TMG) (TMG, Ljubljana, Slovenia) was used to assess mechanical muscle properties of the long head of the rectus femoris (RF) and biceps femoris (BF), knee flexor, and hip extensor muscle from both lower limbs. Participants were asked to remain relaxed. For the $\mathrm{RF}$, a supine position was set, and the knee joint was fixed at $120^{\circ}$; for $\mathrm{BF}$, a prone position was required, and a cushioned pad was used to fix the knee joint at $5^{\circ}$ (Gil et al., 2015).

Previous used TMG measurement protocols were followed in order to standardize the assessment between participants (Rojas-Valverde et al., 2018; Rojas-Valverde, Sánchez-García, Sáenz-Ulloa. \& GutiérrezVargas, 2019; Gutiérrez-Vargas et al., 2018). The participants were asked to remain in a rest position for 5 min. After cleaning the area, two $5 \mathrm{~cm} 2$ adhesive electrodes (TheraTrode, TheraSigma, California, United States of America), with a $5 \mathrm{~cm}$ distance from each other, were placed in the respective muscle avoiding the tendon insertions (García-García, Mendo, Gómez, \& Morales-Sánchez, 2013). The measurement point was set at the maximal radial circumference of RF and BF muscles; it was established visually and by palpation of the muscle during a voluntary contraction (Delagi, Lazzetti, Perotto, \& Morrison, 2011). 
The electrodes were connected to an electrical stimulator (TMG-S2 doo, Ljubljana, Slovenia), that triggers a quadrangular, monophasic, $1 \mathrm{~ms}$ pulse duration wave between 1 to $110 \mathrm{~mA}$. An accurate digital displacement transducer (GK 40, Panoptik doo, Ljubljana, Slovenia) was positioned perpendicular to the previous established measurement point of muscle belly (Delagi et al., 2011). The measurement protocol started triggering at $40 \mathrm{~mA}$ electrical stimulus to induce an involuntary muscle contraction; the electrical stimulus was increased by $20 \mathrm{~mA}$ until the maximal radial displacement was obtained. There was a 10" rest between each stimulus, to avoid fatigue or post-tetanic activation (de Paula Simola et al., 2015).

From TMG measurements, the following parameter was obtained: muscle contraction time (Tc) expressed in ms (ICC $=0.92)$ (Benítez-Jiménez, Fernández-Roldán, Montero-Doblas \& Romacho-Castro, 2013), maximum radial muscle displacement $(\mathrm{Dm})$ in $\mathrm{mm}$ ( $\mathrm{ICC}=0.94$ - 0.97] (Benítez Jiménez, Fernández Roldán, Montero Doblas, \& Romacho Castro, 2013; Tous-Fajardo et al., 2010).

\section{Procedures}

The participants were asked to perform 30' TT in three different conditions with 15 days of recovery. In all conditions, participants were assessed immediately $(5 \mathrm{~min}$ ) pre and post the 30' TT using tensiomyography (TMG), countermovement jump (CMJ), and Delayed Onset Muscle Soreness (DOMS). During the 30' TT distance, speed, thermal index (WBGT), rate of perceived exertion (RPE), and heart rate (HR) were monitored. The study was performed in three different conditions, depending on altitude and temperature, as follows: Control Condition [CC] $\left(1137\right.$ m.a.s.l. at $\left.26 \pm 1.5^{\circ} \mathrm{C}\right)$, Heat-Low Condition [HLC] (3 m.a.s.l. at $\left.30.5 \pm 0.6^{\circ} \mathrm{C}\right)$, and Cool-High Condition [CHC] $\left(2369\right.$ m.a.s.l. at $\left.14.2 \pm 0.6^{\circ} \mathrm{C}\right)$. All tests were performed in an outdoor flat concrete circuit of $400 \mathrm{~m}$ (Figure 1).

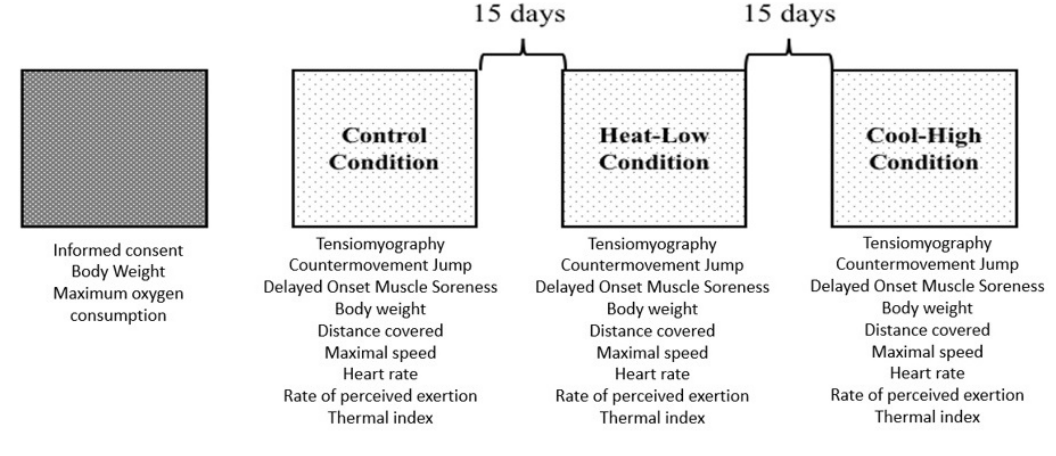

FIGURE 1.

Schematic study design shows the tests performed in the three different conditions with 15 days of recovery.

\section{Statistical Analysis}

Descriptive statistics were implemented through the mean $(\mathrm{M})$ and their respective standard deviations $( \pm S D)$. The Shapiro-Wilk test was used to check the normality of the data of each of the variables. Data of distance, RPE, impacts, HR, and average speed was analyzed using a one-way analysis of variance. Data of weight, DOMS, CMJ, TMG was subjected to a 3 (conditions) x 2 (measures) mixed analysis of variance. The post hoc analysis was done using the Bonferroni method. Percentage of change $(\Delta \%)$, pre and post measurements, was calculated as [(value post - value pre)/value pre] $\times 100$. The magnitudes of the differences for all variables were analyzed using the partial omega squared ( $\omega \mathrm{p} 2)$ for ANOVA analysis. The $\omega \mathrm{p} 2$ values were qualitatively interpreted using the following thresholds: $<0.01$ small; $<0.06$ medium and $<0.14$ large 
MHSALUd, ISSN: 1659-097X, 17(1), ENERo-Junio, 2020, PP 1-14

Rojas-Valverde, Ugalde-Ramírez, Sánchez-Ureña, Gutiérrez-Vargas

(Cohen, 1988). Alpha was set prior to $\mathrm{p}<0.05$. The data analysis was performed using Statistical Package for the Social Sciences (IBM, SPSS Statistics, V 22.0 Chicago, IL, USA).

\section{Results}

Figure 2 shows significant interaction in body weight $(\mathrm{F}(2,57): 4.762, \mathrm{p}=0.012$, $\omega \mathrm{p} 2=0.11)$. After main effect analysis, there was a significant difference between measurement moments $(F(2,57): 625.9, p<0.01$, $\omega \mathrm{p} 2=0.95)$. Body weight decreased significantly after the running in each condition: Control $(\mathrm{F}(2,57)$ : 260.4, $\mathrm{p}<0.01)$, Cool-High $(\mathrm{F}(2,57)$ : 143.6, $\mathrm{p}<0.01)$ and Heat-Low $(\mathrm{F}(2,57): 231.6, \mathrm{p}<0.01)$. No differences betw

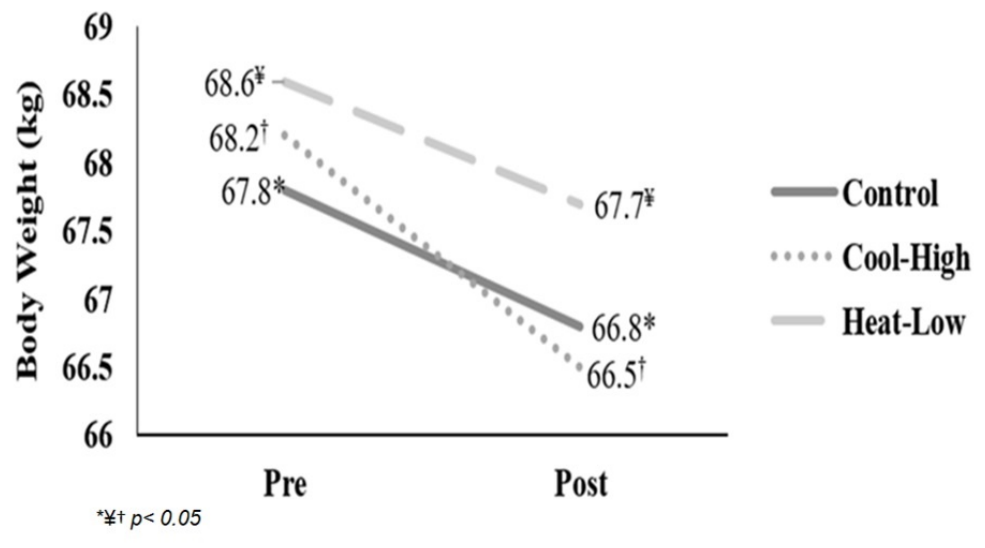

FIGURE 2.

Body weight values pre and post 30' time trial run in each condition.

Figure 3 shows significant interaction in DOMS reported $(\mathrm{F}(2,57): 3.315, \mathrm{p}=0.043$, $\omega \mathrm{p} 2=0.07)$. After main effect analysis, there was a significant difference between measurement moments $(\mathrm{F}(2,57): 323.1$, $\mathrm{p}<0.01, \omega \mathrm{p} 2=0.91)$. DOMS reported increased significantly after the running in each condition: Control $(F(2,57): 87.3, p<0.01)$, Cool-High $(F(2,57): 86.7, p<0.01)$ and Heat-Low $(F(2,57): 155.8, p<0.01)$. No differences between conditions were found $(\mathrm{F}(2,57): 2.785, \mathrm{p}=0.07)$.

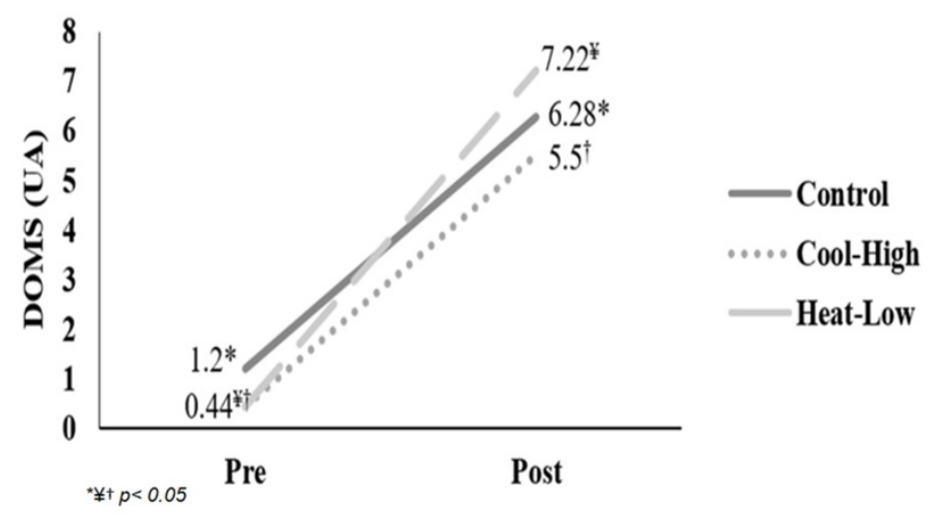

FIGURE 3.

Delayed Onset Muscle Soreness (DOMS) values pre and post 30' TT in each condition.

Figure 4 shows no significant difference among conditions in $\operatorname{RPE}(F(2,57): 0.566, \mathrm{p}=0.571)$, heart rate $(\mathrm{F}(2,57): 0.173, \mathrm{p}=0.841$, ), distance covered $(\mathrm{F}(2,57): 0.150, \mathrm{p}=0.861)$, and maximal speed $(\mathrm{F}(2,57): 0.148$, $\mathrm{p}=0.863)$. 

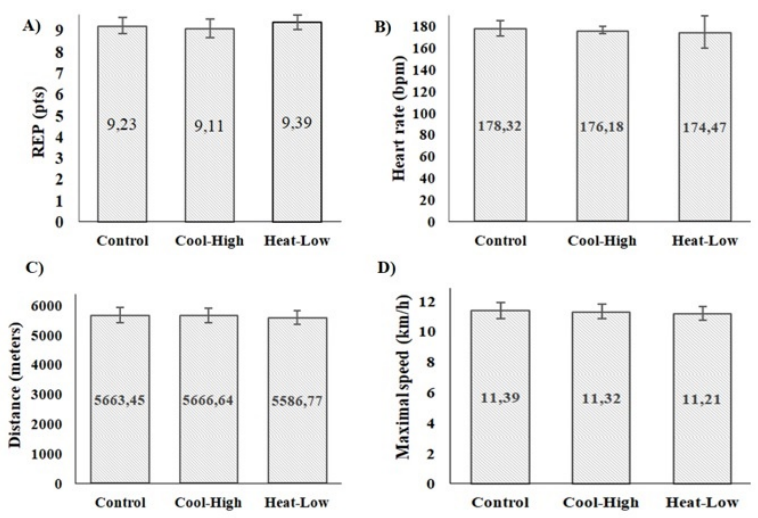

FIGURE 4.

A) Rate of perceived exertion (RPE), B) Heart rate (HR), C) Distance covered, and D) Maximal speed during 30' TT in each condition. Data are presented as means \pm standard deviation.

Table 1 shows no significant interaction in $\operatorname{CMJ}(\mathrm{F}(2,57): 1.218, \mathrm{p}=0.303$, $\omega \mathrm{p} 2=0.01)$. After main effect analysis, there was a significant difference between measurement moments $(\mathrm{F}(2,57): 28.504, \mathrm{p}<0.01$, $\omega \mathrm{p} 2=0.48)$ as follows: Control $(\mathrm{F}(2,57): 8.7, \mathrm{p}<0.01)$, Cool-High $(\mathrm{F}(2,57): 4.2, \mathrm{p}=0.045)$ and Heat-Low $(\mathrm{F}(2,57): 18.02, \mathrm{p}<0.01)$. No differences between conditions were found $(\mathrm{F}(2,57): 1.9, \mathrm{p}=0.162)$.

TABLE 1.

Countermovement jump values pre and post 30' TT in each condition.

\begin{tabular}{lccc}
\hline Condition & Pre (cm) & Post (cm) & $\boldsymbol{\Delta \%}$ \\
\hline Control & $33.21 \pm 3.47$ & $35.41 \pm 3.4 .48$ & 6.62 \\
Cool-High & $31.48 \pm 3.57$ & $33.01 \pm 3.93$ & 4.86 \\
Heat-Low & $32.18 \pm 3.38$ & $35.35 \pm 4.25$ & 9.85 \\
\hline
\end{tabular}

Note: $\mathrm{cm}$ stands for centimeters. Data are presented as means \pm standard deviations and in percent change $(\Delta \%)$.

Table 2 shows no significant interaction for $\mathrm{Tc}(\mathrm{F}(2,57)$ : 1.097, $\mathrm{p}=0.341, \omega \mathrm{p} 2=0)$, and $\operatorname{Dm}(\mathrm{F}(2,57)$ : 1.022, $\mathrm{p}=0.366, \omega \mathrm{p} 2=0)$ in the biceps femoris. However, there was a significant pre-post decrease in $\mathrm{Tc}$ $(\mathrm{F}(2,57): 10.598, \mathrm{p}=0.002, \omega \mathrm{p} 2=0.24)$, and a significant increase in $\operatorname{Dm}(\mathrm{F}(2,57): 10.074, \mathrm{p}=0.00$

TABLE 2.

Tensiomyographic values of the biceps femoris muscle pre and post 30' TT in each condition.

\begin{tabular}{ccccc}
\hline TMG Variable & Condition & Pre & Post & \multicolumn{1}{c}{$\boldsymbol{\Delta \%}$} \\
\hline \multirow{3}{*}{ Tc (ms) } & Control & $32.65 \pm 8.31$ & $27.5 \pm 5.98$ & -15.77 \\
& Cool-High & $35.96 \pm 12.27$ & $31.09 \pm 7.52$ & -13.54 \\
& Heat-Low & $30.85 \pm 8.49$ & $29.49 \pm 6.95$ & -4.41 \\
\hline \multirow{3}{*}{ Dm (mm) } & Control & $5.39 \pm 1.99$ & $5.8 \pm 2.28$ & 7.61 \\
& Cool-High & $4.2 \pm 1.69$ & $4.9 \pm 2.61$ & 16.67 \\
& Heat-Low & $5.14 \pm 1.63$ & $6.4 \pm 1.87$ & 24.51 \\
\hline
\end{tabular}

Note: Tc stands for contraction time; Dm, for maximum radial muscle displacement; $\mathrm{mm}$, for millimeters; $\mathrm{ms}$, for milliseconds. Data are presented as means \pm standard deviations and in percentage change $(\Delta \%)$.

Table 3 shows no significant interaction for $\mathrm{Tc}(\mathrm{F}(2,57): 2.409, \mathrm{p}=0.099, \omega \mathrm{p} 2=0.04)$, and $\mathrm{Dm}(\mathrm{F}(2,57)$ : $1.117, \mathrm{p}=0.334, \omega \mathrm{p} 2=0)$ in the rectus femoris muscle. However, there was a significant pre-post decrease 
in $\operatorname{Tc}(\mathrm{F}(2,57)$ : 33.824, $\mathrm{p}<0.01, \omega \mathrm{p} 2=0.52)$, and a significant increase in $\mathrm{Dm}(\mathrm{F}(2,57): 36.25, \mathrm{p}<0.01$, $\omega \mathrm{p} 2=0.54)$.

TABLE 3.

Tensiomyographic values of the rectus femoris muscle pre and post 30' TT in each condition.

\begin{tabular}{ccccc}
\hline $\begin{array}{c}\text { TMG } \\
\text { Variable }\end{array}$ & Condition & Pre & Post & $\boldsymbol{\Delta \%}$ \\
\hline \multirow{3}{*}{ Tc (ms) } & Control & $30.51 \pm 4.59$ & $26.1 \pm 3.47$ & -14.45 \\
& Cool-High & $31.22 \pm 3.59$ & $28.81 \pm 2.75$ & -7.72 \\
& Heat-Low & $29.17 \pm 4.29$ & $27.31 \pm 3.22$ & -6.37 \\
\hline \multirow{3}{*}{ Dm (mm) } & Control & $8.22 \pm 1.88$ & $9.11 \pm 1.69$ & 10.83 \\
& Cool-High & $7.95 \pm 2.18$ & $9.45 \pm 1.95$ & 18.87 \\
& Heat-Low & $7.66 \pm 2.45$ & $9.35 \pm 1.9$ & 22.06 \\
\hline
\end{tabular}

Note: Tc stands for contraction time; Dm, for maximum radial muscle displacement; mm, for millimeters; $\mathrm{ms}$, for milliseconds. Data are presented as means \pm standard deviations and in percent change $(\Delta \%)$.

\section{Discussion}

The main purpose of this study is to explore the influence of environmental temperature and altitude on muscle functional and mechanical activation after 30' TT. For this, a group of twenty physical active males was assessed in three different conditions of altitude and temperature: Control Conditions [CC] (1137 m.a.s.l. at $\left.26 \pm 1.5^{\circ} \mathrm{C}\right)$, Heat-Low Conditions [HLC] $\left(3\right.$ m.a.s.l. at $\left.30.5 \pm 0.6^{\circ} \mathrm{C}\right)$, and Cool-High Conditions [CHC] $\left(2369\right.$ m.a.s.l. at $\left.14.2 \pm 0.6^{\circ} \mathrm{C}\right)$.

As main results, a significant bodyweight decrease was registered after the running in each condition. It is common that an individual loses body weight during and after a physical effort, mainly caused by loss of liquid. In this study, participants had the greatest body weight (around 2\% approximately of body weight) in the cool-high condition. In higher altitude, environmental conditions such as less humidity and air density, as well as more radiation, may stimulate the loss of liquid due to perspiration and water evaporation. Furthermore, inhaled dry air must be humidified with water vapor when entering the respiratory system (Mazzeo, 2008).

The participants in this study perceived more DOMS in low-heat conditions compared to the other two scenarios; this may be due to the effect of higher heat stress perceived during exercising in the heat (Schlader, Stannard \& Mundel, 2009). It is common that, during and after physical exertions, the sensation of pain increases although, it can also be maintained between 6 to 8 hours after the effort is made (Vanshika, 2012). The sensation of pain increases during and after a race due to the micro-ruptures of muscle and muscletendinous fibers, which causes an inflammatory response (Lewis, Ruby, \& Bush-Joseph, 2012). Likewise, when individuals perform physical exercise under heat conditions, they perceive a greater sensation of fatigue and acute pain than in other environments due to the high metabolic demands necessary to execute all the processes of loss of body heat (Schlader, Stannard, \& Mundel, 2009).

In the present study, it was observed that the meters covered, heart rate, maximum speed, and RPE were similar in three conditions; in fact, no difference was found. Therefore, taking these variables as intensity indicators for each condition, it seems that altitude and temperature did not influence nor affect the subjects' performance during the 30 minutes of running. The evidence recovered suggests that in hypoxia or moderate hypoxia, fatigue appears faster than in normoxia conditions, and usually, physical performance decreases, resulting from muscle fatigue that affects the recruitment of the nervous system (Feriche et al., 2014). 
Referring to contractile responses, the results of this study did not indicate differences in the Tc and $\mathrm{Dm}$ values among the three conditions, and neither did the performance test (CMJ). These results seem to be congruent with the literature. In hypoxia and moderate altitude, changes in muscle contractions are limited (Feriche et al., 2014). Studies carried out using other evaluation techniques of muscle properties do not evidence changes in hypoxia. For example, using electrically evoked isometric contractions did not generate a significant impact of acute hypoxia on contractile properties of skeletal muscle; however, there was a decrease in endurance during low-level sustained voluntary contractions (Degens et al., 2006). Also, there was a notorious impairment of bicep brachii muscle isometric endurance performance during a period of acclimatization at altitude (Felici et al., 2001). On this line, during sustained fatiguing contractions in normoxic and hypoxic, it is not different in peripheral and neuromuscular responses (Szubski et al., 2007).

However, in this study, it was found that, after $30^{\prime} \mathrm{TT}$, there was a significant decrease in Tc and an important increase in Dm. When comparing these results with previously conducted studies, it was established that the values of TMG measurements are similar to the values previously obtained by comparing the contractile responses in hypoxia and normoxia conditions. Nevertheless, these authors found that Dm values of biceps femoris diminish significantly under hypoxic conditions. On the other hand, Tc did not change drastically (Morales-Artacho et al., 2015). Other studies, which also have used TMG to measure muscle properties with participants of ultra-endurance, reported that, after an event, the muscle shows higher $\mathrm{Dm}$, which is similar to the outcome obtained in the present research (García-Manso et al., 2011).

Also, this study shows that CMJ performance was significantly improved during post measurement. This result is in concordance with the results found in elite resistance runners who improved jump capacity and power of the lower limbs after a running protocol of 40 minutes at $80 \%$ to determine the maximal aerobic speed in a laboratory test (Vuorimaa et al., 2006). Similarly, in twelve male athletes with an average age of 23.2 \pm 3.3 years, there were improvements in jump height after two different field running protocols (Montreal Track Test vs. Tlim), especially after the second minute of recovery (Boullosa \& Tuimil, 2009); this may give a greater idea of how different endurance intensive efforts could lead to similar PAP results.

Improvement in explosive actions is a PAP effect commonly found during the research (Gouvêa et al., 2012; Seitz \& Haff, 2016; Wilson et al., 2013). This neuromuscular effect may be attributed to the increased activity of the higher motor centers; a rise in the number of motor units recruited in neural activity improves nerve impulses allowing faster movements (Chatzopoulos et al., 2007; DeRenne, 2010; Wilson et al., 2013). The stimulus and the workload increase in sarcoplasmic $\mathrm{Ca} 2+$, enhanced phosphorylation process of the myosin light chain, and actin-myosin cross-bridging (Lorenz, 2011). Likewise, when the enhancing effect remains after the fatigue has disappeared is when it may show improvements in the contractile responses (Gołaś et al., 2016; Xenofondos et al., 2010).30' TT could develop PAP because it will not cause the necessary fatigue to block the muscle contraction process; instead, this intensive endurance effort may lead to an optimization of muscle function (Carrol, Taylor \& Gandevia, 2017).

Future research may explore the potential of this kind of stimulus more in depth to improve mechanical and functional muscle performance. The effects of low, moderate, and high-intensity exercises, as well as different durations and types of exercises in PAP in the different stages according to temperature and altitude, should be explored in greater detail. Finally, future research could explore the impact of contextual factors such as age, physical activity, sport, acclimation to different environments, and other contextual variables on PAP and muscle responses. It could also dive into the study of other factors such as medication, dehydration, heat strain, and health status that could trigger a higher or lower potentiation. There is a necessity of new evidence around the effect of different types of exercise in biochemical muscle fatigue markers and their influence on PAP.

While the results of this study have provided valuable information about the influence of altitude and environmental temperature on PAP after 30' TT running, some limitations must be acknowledged. Because of the organic nature of field assessments, as in the present study, the authors were not allowed to control 
some contextual factors that could influence the muscle responses such as rest, stimulation by substance ingestion, and physical activity prior to trials, among others. Due to the organic exploration of the real setting conditions during and after running, some factors such as food intake and liquid intake were not monitored and were led ad libitum. After running, recovery strategies were not restricted but registered as an internal control. As expected, these results must be addressed considering the specific anthropometry, experience, and physical level of the analyzed sample; they should not be extrapolated to other populations that show different characteristics.

\section{CONCLUSION}

The results of this study show that altitude and temperature after 30' TT did not considerably affect the mechanical and functional responses in CMJ test, contractile responses measured using TMG, distances covered, HR, and maximal speed.

Nevertheless, endurance intensive effort exercises, prior to potency tests, provide a $6.6 \%$ improvement in CMJ performance and muscle contraction time from $9 \%$ to $11 \%$, as well as muscle stiffness increased from $13 \%$ to $19 \%$.

\section{REFERENCIAS}

measuring vertical jump performance. Journal of Sports Science, 33(15), 1574-1579. https://doi.org/10.1080

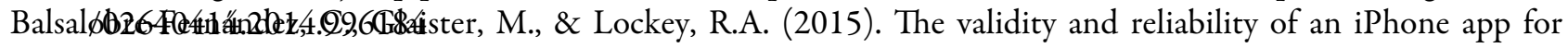

Benítez Jiménez, A., Fernández Roldán, K., Montero Doblas, J. M., \& Romacho Castro, J. A. (2013). Reliability of tensiomiography (TMG) as a muscle assessment tool. Revista Internacional de Medicina y Ciencias de la Actividad Fisica y Deporte, 13(52), 647-656.

Bevan, H. R., Cunningham, D. J., Tooley, E. P., Owen, N. J., Cook, C. J., \& Kilduff, L. P. (2010). Influence of postactivation potentiation on sprinting performance in professional rugby players. The Journal of Strength \& Conditioning Research, 24(3), 701-705. https://doi.org/10.1519/JSC.0b013e3181c7b68a

Boullosa, D. A., Tuimil, J. L. (2009). Postactivation potentiation in distance runners after two different field running protocols. The Journal of Strength \& Conditioning Research, 23(5), 1560-1565. https://doi.org/10.1519/JSC $.0 \mathrm{~b} 013 \mathrm{e} 3181 \mathrm{a} 3 \mathrm{ce} 61$

Carrol, T.J., Taylor, J.L., \& Gandevia. (2017). Recovery of central and peripheral neuromuscular fatigue after exercise. Journal of Applied Physiology, 122(5): 1068-76.

Chatzopoulos, D. E., Michailidis, C. J., Giannakos, A. K., Alexiou, K. C., Patikas, D. A., Antonopoulos, C. B., \& Kotzamanidis, C. M. (2007). Postactivation potentiation effects after heavy resistance exercise on running speed. The Journal of Strength \& Conditioning Research, 21(4), 1278-1281. https://doi.org/10.1519/R-21276.1

Cohen, J. (1988). Statistical Power Analysis for the Behavioral Sciences. New York: Routledge Academic.

de Paula Simola, R. Á., Harms, N., Raeder, C., Kellmann, M., Meyer, T., Pfeiffer, M., \& Ferrauti, A. (2015). Assessment of neuromuscular function after different strength training protocols using tensiomyography. The Journal of Strength \& Conditioning Research, 29(5), 1339-1348. https://doi.org/10.1519/JSC.0000000000000768

Degens, H., Horneros, J. M. S., \& Hopman, M. T. (2006). Acute hypoxia limits endurance but does not affect muscle contractile properties. Muscle \& Nerve, 33(4), 531-537. https://doi.org/10.1002/mus.20485

Delagi, E., Lazzetti, J., Perotto, A., \& Morrison, D. (2011). Anatomical Guide For The Electromyographer The Limbs and Trunk (pp.4-397). Charles C Thomas Publisher LTD, Fifht Ed., Ilinois, United States of America.

DeRenne, C. (2010). Effects of postactivation potentiation warm-up in male and female sport performances: A brief review. Strength \& Conditioning Journal, 32(6),58-64. https://doi.org/10.1519/SSC.0b013e3181f412c4 
MHSALUD, ISSN: 1659-097X, 17(1), ENERO-JUNIO, 2020, PP 1-14 Rojas-Valverde, Ugalde-Ramírez, Sánchez-Ureña, Gutiérrez-Vargas

Esformes, J. I., Cameron, N., \& Bampouras, T. M. (2010). Postactivation potentiation following different modes of exercise. The Journal of Strength \& Conditioning Research, 24(7), 1911-1916. https://doi.org/10.1519/JSC.0b $013 \mathrm{e} 3181 \mathrm{dc} 47 \mathrm{f} 8$

Felici, F., Rosponi, A., Sbriccoli, P., Scarcia, M., Bazzucchi, I., \& Iannattone, M. (2001), Effect of human exposure to altitude on muscle endurance during isometric contractions. European Journal of Applied Physiology, 85(6), 507-512. https://doi.org/10.1007/s004210100488

Feriche, B., García-Ramos, A., Calderón-Soto, C., Drobnic, F., Bonitch- Góngora, J. G., Galilea, P. A.,... \& Padial, P. (2014). Effect of acute exposure to moderate altitude on muscle power: hypobaric hypoxia vs. normobaric hypoxia. PLoS One, 9(12), e114072. https://doi.org/10.1371/journal.pone.0114072

García-García, O., Mendo, A. H., Gómez, V. S., \& Morales-Sánchez, V. (2013). Aplicación de la teoría de la generalizabilidad a un análisis de tensiomiografía en ciclistas profesionales de ruta. Revista de Psicología del Deporte, 22(1), 53-60.

García-Manso, J. M., Rodríguez-Ruiz, D., Rodríguez-Matoso, D., de Saa, Y., Sarmiento, S., \& Quiroga, M. (2011). Assessment of muscle fatigue after an ultra-endurance triathlon using tensiomyography (TMG).Journal of Sports Science, 29(6), 619-625. https://doi.org/10.1080/02640414.2010.548822

Geiser, J., Vogt, M., Billeter, R., Zuleger, C., Belforti, F., \& Hoppeler, H. (2001). Training high-living low: changes of aerobic performance and muscle structure with training at simulated altitude. International Journal of Sports Medicine, 22(08), 579-585. https://doi.org/10.1055/s-2001-18521

Gil, S., Loturco, I., Tricoli, V., Ugrinowitsch, C., Kobal, R., Abad C. C., \& Roschel, H. (2015). Tensiomyography parameters and jumping and sprinting performance in Brazilian elite soccer players. Sports Biomechanics; 14(3), $340-50$.

Gołaś, A., Maszczyk, A., Zajac, A., Mikołajec, K., \& Stastny, P. (2016). Optimizing post activation potentiation for explosive activities in competitive sports. Journal of Human Kinetic, 52(1), 95-106. https://doi.org/10.1515/h ukin-2015-0197

Gouvêa, A. L., Fernandes, I. A., César, E. P., Silva, W. A. B., \& Gomes, P. S. C. (2013). The effects of rest intervals on jumping performance: A meta-analysis on post-activation potentiation studies. Journal of Sports Science, 31(5), 459-467. https://doi.org/10.1080/02640414.2012.738924

Gulick, D. T., Kimura, I. F., Sitler, M., Paolone, A., \& Kelly I.V, J. D. (1996). Various treatment techniques on signs and symptoms of delayed onset muscle soreness. Journal of Athletic Training, 31(2), 145.

Gutiérrez-Vargas, R., Martín-Rodríguez, S., Sánchez-Ureña, B., Rodríguez-Montero, A., Salas-Cabrera, J., GutiérrezVargas, JC., Šimunič, B. \& Rojas-Valverde, D. (2018). Biochemical and muscle mechanical post-marathon changes in hot and humid conditions. Journal of Strength and Conditioning Research. https://doi.org/10.15 19/JSC.0000000000002746

Hamlin, M.J., Hopkins, W.G., \& Hollings, S.C. (2015). Effects of altitude on performance of elite track-and-field athletes. International Journal of Sports Physiology Performance, 10(7), 881-887. https://doi.org/10.1123/ijspp .2014-2061

Johnston, R. J., Watsford, M. L., Kelly, S. J., Pine, M. J., \& Spurrs, R. W. (2014). Validity and interunit reliability of $10 \mathrm{~Hz}$ and $15 \mathrm{~Hz}$ GPS units for assessing athlete movement demands. The Journal of Strength \& Conditioning Research, 28(6), 1649-1655. https://doi.org/10.1519/JSC.0000000000000323

Lewis, P. B., Ruby, D., \& Bush-Joseph, C. A. (2012). Muscle soreness and delayed-onset muscle soreness. Clinics in Sports Medicine, 31(2), 255-262. https://doi.org/10.1016/j.csm.2011.09.009

Lorenz, D. (2011). Postactivation potentiation: An introduction. International Journal of Sports Physical Therapy, 6(3), 234-240. PMID: 21904700

Lundby, C., Millet, G. P., Calbet, J. A., Bärtsch, P., \& Subudhi, A. W. (2012). Does 'altitude training' increase exercise performance in elite athletes? British Journal of Sports Medicine, 46(11), 792-795. http://dx.doi.org/10.1136/ bjsports-2012-091231 
MHSALUd, ISSN: 1659-097X, 17(1), ENEro-Junio, 2020, PP 1-14

Rojas-Valverde, Ugalde-Ramírez, Sánchez-Ureña, Gutiérrez-Vargas

Martínez-López EJ. (2004) Aplicación de la prueba de Cooper, Course Navette y test de Ruffier. Resultados y análisis estadístico en Educación Secundaria. Revista Internacional de Medicina y Ciencias de la Actividad Física y Deporte, 4(15), 163-82.

Mazzeo, R. S. (2008). Physiological responses to exercise at altitude: an update. Physiological Responses to Exercise at Altitude: An Update. Sports Medicine, 38(1), 1-8. https://doi.org/10.2165/00007256-200838010-00001

Mettler, J. A., \& Griffin, L. (2012). Postactivation potentiation and muscular endurance training. Musles \& Nerve, 45(3), 416-425. https://doi.org/10.1002/mus.22313

Morales-Artacho, A. J., Padial, P., Rodríguez-Matoso, D., Rodríguez-Ruiz, D., García-Ramos, A., García-Manso, J. M.,..., \& Feriche, B. (2015). Assessment of muscle contractile properties at acute moderate altitude through tensiomyography. High Altitude and Medicine Biology, 16(4), 343-349. https://doi.org/10.1089/ham.2015.0 078

Pastor Y, Balaguer I., \& García-Merita, M.L. (1999). Estilo de vida y salud. Valencia: Albatros Educación.

Picón-Martínez, M., Chulvi-Medrano, I., Cortell-Tormo, J.M. \& Cardozo, L.A. (2019). La potenciación postactivación en el salto vertical: una revisión. Retos, 36: 44-51.

Pino-Ortega, J., Bastida-Castilo, A., Oliva-Lozano, J.M., Rojas-Valverde, D., Reche-Soto, P. \& Gómez-Carmona, C. (2019). Comparación de dos métodos de detección para el registro de la frecuencia cardíaca: banda torácica vs camiseta técnica. Retos: Nuevas Tendencias en Educación Física, Deporte y Recreación, 36: 469-73.

Rojas-Valverde, D., Gutiérrez-Vargas, R., Rodríguez-Montero, A., Pereira, L., Loturco, I. \& Martín-Rodríguez, S. (2018). Reduced muscle contractile function in elite young soccer players after a short-congested fixture period. Proceedings in Mechanical Engineering; Part P: Journal of Sports Engineering and Technology. 20. https://do i.org/10.1177/1754337118817957

Rojas-Valverde, D., Sánchez-García, A., Sáenz-Ulloa, D. \& Gutiérrez-Vargas, R. (2019). Osteopathic manipulation improves physical and muscle mechanical function and spinal symmetries in golfers. Revista Kronos: Actividad Física y Deporte, 18(1). https://g-se.com/does-osteopathic-manipulation-lead-to-improvements-in-physical-an d-muscle-mechanical-function-and-spinal-symmetries-in-golfers-2572-sa-B5d0bd405de00b

Sánchez-Ureña, B., Rojas-Valverde, D. \& Gutiérrez-Vargas R. (2018). Acute immersion protocol is not effective for neuromuscular mechanical function recovery: a tensiomyography study. Frontiers in Physiology, 9 (766). https ://doi.org/10.3389/fphys.2018.00766

Schlader ZJ, Stannard SR, \& Mundel T. (2009). Exercise and Heat Stress: Performance, Fatigue, and Exhaustion-A HOT Topic. British Journal of Sports Medicine, 45(1), 1-5. https://doi.org/10.1136/bjsm.2009.063024

Seitz, L. B., \& Haff, G. G. (2016). Factors modulating post-activation potentiation of jump, sprint, throw, and upperbody ballistic performances: A systematic review with meta-analysis. Sports Medicine, 46(2), 231-240. https:// doi.org/10.1007/s40279-015-0415-7

Szubski, C., Burtscher, M., \& Löscher, W. N. (2007). Neuromuscular fatigue during sustained contractions performed in short-term hypoxia. Medicine Science of Sports Exercise, 39(6), 948-954. https://doi.org/10.1249/mss.0b013 e3180479918

Tano, G., Bishop, A., Berning, J., Adams, K. J., \& DeBeliso, M. (2016). Post activation potentiation in North American high school football players. Journal of Sports Science, 4(6), 346-352. https://doi.org/10.17265/2332-7839/20 16.06.003

Tous-Fajardo, J., Moras, G., Rodríguez-Jiménez, S., Usach, R., Doutres, D. M., \& Maffiuletti, N. A. (2010). Interrater reliability of muscle contractile property measurements using non-invasive tensiomyography. Journal of Electromyography and Kinesiology, 20(4), 761-766. https://doi.org/10.1016/j.jelekin.2010.02.008

Vanshika S. (2012). Literature review of management of delayed onset muscle soreness (DOMS). International Journal of Biological and Medical Research, 3(1), 1469-1475.

Vuorimaa, T, Virlander, R, Kurkilahti, P, Vasankari, T, \& Häkkinen, K. (2006). Acute changes in muscle activation and leg extension performance after different running exercises in elite long distance runners. European Journal of Applied Physiology, 96(3), 282-291. 
MHSALUD, ISSN: 1659-097X, 17(1), ENERO-JUNIO, 2020, PP 1-14 Rojas-Valverde, Ugalde-Ramírez, Sánchez-Ureña, Gutiérrez-Vargas

Wilson, J. M., Duncan, N. M., Marin, P. J., Brown, L. E., Loenneke, J. P., Wilson, S. M., ... \& Ugrinowitsch, C. (2013). Meta-analysis of postactivation potentiation and power: effects of conditioning activity, volume, gender, rest periods, and training status. The Journal of Strength \& Conditioning Research, 27(3), 854-859. https://doi.or $\mathrm{g} / 10.1519 / \mathrm{JSC} .0 \mathrm{~b} 013 \mathrm{e} 31825 \mathrm{c} 2 \mathrm{bdb}$

World Medical Association. (2013). Declaration of Helsinki of the World Medical Association. Ethical principles for medical research in humans. 64th WMA General Assembly, Fortaleza, Brazil (Online). (Consulted 2018 Oct 20). Available from: https://www.wma.net/policies-post/wma-declaration-of-helsinki-ethical-principles-for-medic al-research-involving-human-subjects/

Xenofondos, A., Laparidis, K., Kyranoudis, A., Galazoulas, C., Bassa, E., \& Kotzamanidis, C. (2010). Post-activation potentiation: Factors affecting it and the effect on performance. Journal of Physical Education and Sport, 28(3), $32-38$.

CC BY-NC-ND 